\title{
Performance Evaluation of Ferns for Cut Green and Landscape Purpose
}

\author{
Mini Sankar, Sudhadevi P.K., Geetha C.K., Roshmi Kurian and Shilpa P. \\ Department of Floricultureand Landscaping, College of Horticulture \\ Kerala Agricultural University, Vellanikkara, Thrissur, India. \\ Corresponding author email: drminisankar@gmail.com
}

\begin{abstract}
Ferns can be used as ground covers, specimen plants and for group, background and border planting in landscape. They can also be used as fillers in bouquets and flower arrangements. Hence, the objective of the study was to evaluate the performance of different fern species and to identify the suitable species for commercial cultivation. Eleven species of ferns belonging to different genera viz., Adiantum tenerum, Asplenium nidus, Asplenium longissimum, Asplenium scolopendrium, Diaplazium acrostichoides, Nephrolepis biserrata 'furcans', Nephrolepis exaltata 'chidisii', Nephrolepis exaltata, Bostoniensis compacta, Nephrolepis cordifolia, Nephrolepis biserrata miniata and Pteris ensiformis were evaluated for growth pattern and suitability for landscape and commercial uses. Vegetative characters like eplant height and spread were highest in Asplenium nidus and a maximum number of leaves were observed in Adiantum tenerum. Based on growth pattern they were classified under tall, medium and dwarf groups Asplenium nidus and Nephrolepis biserrata miniata were grouped under the tall category. The species which come under medium category are Asplenium longissimum, Diaplazium acrostichoides, Nephrolepis biserrata 'Furcans', Nephrolepis exaltata 'Chidisii', Nephrolepis exaltata, Bostoniensis compacta, Nephrolepis cordifolia, Pteris ensiformis and Asplenium scolopendrium where as Adiantum tenerum comes under dwarf category. All species evaluated were found to be suitable for pot plants. Nephrolepis biserrata miniata, Nephrolepis biserrata furcans, Nephrolepis cordifolia, Asplenium nidus and Diaplazium acrostichoides can be recommended as houseplants. Nephrolepis biserrata-Miniata, Nephrolepis biserrata furcans and Nephrolepis cordifolia can be used as border plants in landscapes. Nephrolepis exaltata, Bostoniensis compacta, Asplenium longissimum and Pteris ensiformis were observed to be attractive in hanging baskets. Nephrolepis biserrata-Miniata, Nephrolepis exaltata chidisii, Nephrolepis exaltata, Bostoniensis compacta and Diaplazium acrostichoides are suitable for bouquets and flower arrangements.
\end{abstract}

Keywords: Cut green, Evaluation, Ferns and Landscape

\section{INTRODUCTION}

Ferns are heterogeneous group of vascular plants widely distributed in humid and shady habitats. They are tropical flowerless plants and most of the species are low growing and herbaceous in nature. Ferns are excellent materials, which can provide greenery in a landscape. They are adapted to shady areas and they can be used to enhance the indoor environmental conditions. The great diversity of the ferns make them exceptional landscape materials and the characteristic features of foliage make them excellent fillers in flower arrangements, bouquets etc. large number of fern species having great ornamental value are seen widely grown in Kerala especially in western ghat regions. There is a tremendous potential for exploring the commercial and landscape value of these ferns. Due to the varied forms, shape and long post harvest life of their fronds, they are highly recommended as filler materials in bouquets and flower arrangements. There are numerous species of ferns grown in Kerala, the landscape and commercial value of those are yet to be exploited. There is a need to collect and evaluate those potential groups to introduce new 
species to the floriculture industry in Kerala. Hence, the study was aimed to collect the ferns available in humid forest regions of Kerala and evaluate the performance of different fern species and to identify the suitable species for commercial cultivation.

\section{MATERIALS AND METHODS}

The study was carried out in the Department of Floriculture and Landscaping, College of Horticulture, Vellanikkara. Eleven species of ferns from the existing germplasm collection viz; Adiantum tenerum, Asplenium nidus, Asplenium longissimum, Asplenium scolopendrium, Diaplazium acrostichoides, Nephrolepis biserrata 'Furcans', Nephrolepis exaltata 'Chidisii', Nephrolepis exaltata Bostoniensis compacta, Nephrolepis cordifolia, Nephrolepis biserrata-Miniata and Pteris ensiformis were selected for evaluation. The experiment was laid out in CRD with three replications. Standard cultural practices were followed throughout the study period. The observations on following quantitative parameters viz., plant height, plant spread, number of leaves per plant, longevity of leaf on plant, leaf production interval and vase life were recorded. The qualitative traits such as texture of frond, shape of frond, nature of margin, nature of tip, presence of marking/pigments, colour of frond, branching habit and reaction to peat and diseases were also recorded.

\section{RESULTS AND DISCUSSION}

\section{Quantitative characters}

Morphological characters of different species of ferns are given in the Table 1. Among vegetative characters, plant height is an important parameter and based on the plant height categorization of plants can be done for various landscape uses. Plant height was maximum in species Asplenium nidus $(113.00 \mathrm{~cm})$ and minimum plant height was observed in Adiantum tenerum $(12.33 \mathrm{~cm})$. The species Asplenium nidus was also superior regarding plant spread $(144.00 \mathrm{~cm}$ NS and $159.00 \mathrm{~cm}$ in EW). Number of leaves per plant were recorded the highest in Adiantum tenerum (159.70). Since foliage is the attractive part of ferns, longevity of leaf on a plant is very important and in the present study the maximum value for this parameter was observed in Asplenium nidus (292.30) followed by Nephrolepis biserrata miniata (209.30).
Similar findings were also reported by Oloyede, (2012).

\section{Leaf production interval}

Post harvest longevity of fronds decides the commercial value of ferns since they are mainly used as cut foliage and filler materials. Vase life was maximum in Asplenium longissimum and Asplenium nidus (10 days) and minimum vase life was observed in Diaplazium acrostichoides (table 1).

\section{Qualitative characters}

Among the qualitative characters, leaf texture was smooth in all the species except Diaplazium acrostichoides in which the texture was rough compared to other species. The shape of frond ranges from reniform to lanceolate. The colour of the fronds ranges from light green to dark green and all species evaluated were resistant to pests and diseases except Diaplazium acrostichoides, which was susceptible to leaf spot disease. Variation in quantitative and qualitative characters of ferns may be due to the peculiar genetic makeup of each genotype as reported by Safeena (2013) and Vasco et al. (2013).

Based on the performance, suitable species for various landscape uses were identified. All species evaluated were found to be suitable for pot plants. Nephrolepis biserrata miniata, Nephrolepis biserrata furcans, Nephrolepis cordifolia, Asplenium nidus and Diaplazium acrostichoides can be recommended as indoor plants. This is in accordance with the findings of Lerner, (2001) who reported the suitability of the ferns as indoor plants. Nephrolepis biserrata-Miniata, Nephrolepis biserrata furcans and Nephrolepis cordifolia can be used as border plants in landscapes. Adiantum tenerum is a very low growing fern with soft textured attractive leaves and this can be recommended ground covers in shady areas. Bharathi et al., (2013) had also reported ferns as excellent as ground cover in shady areas. Nephrolepis exaltata Bostoniensis compacta, Asplenium longissimum and Pteris ensiformis were observed to be attractive in hanging baskets. Nephrolepis biserrata-Miniata, Nephrolepis exaltata chidisii, Nephrolepis exaltata Bostoniensis compacta, Nephrolepis cordifolia and Diaplazium acrostichoides are suitable as cut foliage can be used for bouquets and flower arrangements. The popularity 
of ferns as cut foliage had also been reported by Stamps and Conover, (1986) and Safeena, (2013).

Hence, it can be concluded that, all ferns evaluated were suitable for landscape and pot plant purpose, Nephrolepis biserrata miniata, Nephrolepis biserrata furcans, Nephrolepis cordifolia, Asplenium nidus and Diaplazium acrostichoides can be recommended as indoor plants. Nephrolepis biserrata-Miniata, Nephrolepis biserrata furcans and Nephrolepis cordifolia can be used as border plants in landscapes. Adiantum tenerum is a very low growing fern with soft textured attractive leaves and this can be recommended ground covers in shady areas. Nephrolepis exaltata Bostoniensis compacta, Asplenium longissimum and Pteris ensiformis were observed to be attractive in hanging baskets. Nephrolepis biserrata-Miniata, Nephrolepis exaltata chidisii, Nephrolepis exaltata Bostoniensis compacta, Nephrolepis cordifolia and Diaplazium acrostichoides are suitable as cut foliage.

Table 1: Evaluation of different species of ferns for vegetative characters

\begin{tabular}{|c|c|c|c|c|c|c|c|}
\hline Species/Varieties & $\begin{array}{c}\text { Plant } \\
\text { height } \\
\text { (cm) }\end{array}$ & $\begin{array}{c}\text { Plant } \\
\text { spread } \\
\text { NS (cm) }\end{array}$ & $\begin{array}{c}\text { Plant } \\
\text { spread } \\
\text { EW }(\mathrm{cm})\end{array}$ & $\begin{array}{c}\text { No. of } \\
\text { leaves } \\
\text { per plant }\end{array}$ & $\begin{array}{c}\text { Longevity } \\
\text { Longevity } \\
\text { plant }\end{array}$ & $\begin{array}{c}\text { Leaf } \\
\text { production } \\
\text { interval }\end{array}$ & $\begin{array}{c}\text { Vase } \\
\text { life } \\
\text { (days) }\end{array}$ \\
\hline Aspleniumlongissimum & 33.75 & 44.67 & 46.00 & 37.30 & 152.00 & 22.00 & 10.00 \\
\hline Nephrolepisexaltatachildsii & 37.25 & 45.00 & 46.00 & 29.70 & 181.00 & 12.00 & 7.30 \\
\hline Nephrolepisexaltata & 40.42 & 53.33 & 49.80 & 26.30 & 124.30 & 15.30 & 6.70 \\
\hline Pterisensiformis & 57.25 & 65.00 & 72.80 & 63.80 & 94.30 & 11.70 & 4.70 \\
\hline Diplaziumacrostichoides & 49.83 & 62.67 & 61.20 & 14.50 & 91.30 & 19.70 & 3.30 \\
\hline Nephrolepiscordifolia & 48.83 & 57.92 & 54.30 & 91.80 & 181.00 & 14.00 & 9.30 \\
\hline Nephrolepisbiserrataminata & 77.67 & 82.00 & 85.70 & 31.00 & 209.30 & 10.70 & 7.30 \\
\hline Adiantumtenerum & 12.33 & 21.33 & 21.50 & 157.00 & 178.30 & 12.30 & 7.00 \\
\hline Aspleniumscolopendrium & 69.67 & 78.17 & 77.70 & 24.30 & 85.70 & 24.30 & 5.70 \\
\hline Aspleniumnidus & 113.00 & 144.00 & 159.70 & 21.30 & 292.30 & 155.70 & 10.00 \\
\hline $\begin{array}{l}\text { Nephrolepisbiserrata } \\
\text { var. furcans }\end{array}$ & 27.83 & 40.08 & 41.20 & 34.50 & 149.00 & 17.70 & 6.70 \\
\hline Range & $\begin{array}{l}12.33- \\
113.00\end{array}$ & $\begin{array}{l}40.88- \\
144.00\end{array}$ & $\begin{array}{l}21.50- \\
159.70\end{array}$ & & & & \\
\hline $\mathrm{CD}(0.05)$ & 15.23 & 14.29 & 17.90 & 13.60 & 15.60 & 6.90 & \\
\hline
\end{tabular}


Table 2: Evaluation of different species of fern for qualitative characters

\begin{tabular}{|c|c|c|c|c|c|c|c|}
\hline $\begin{array}{l}\text { Species/ } \\
\text { Varieties }\end{array}$ & $\begin{array}{l}\text { Texture } \\
\text { of frond }\end{array}$ & $\begin{array}{l}\text { Shape of } \\
\text { frond }\end{array}$ & $\begin{array}{l}\text { Nature of } \\
\text { margin }\end{array}$ & $\begin{array}{l}\text { Nature } \\
\text { of tip }\end{array}$ & $\begin{array}{c}\text { Presence } \\
\text { of } \\
\text { marking/ } \\
\text { pigments }\end{array}$ & $\begin{array}{l}\text { Colour of } \\
\text { frond }\end{array}$ & $\begin{array}{c}\text { Reaction to } \\
\text { pests and } \\
\text { diseases }\end{array}$ \\
\hline Aspleniumlongissimum & Smooth & Oblong & Undulate & $\begin{array}{l}\text { Emargi } \\
\text { nated }\end{array}$ & Absent & Dark green & Resistant \\
\hline $\begin{array}{l}\text { Nephrolepisexaltata- } \\
\text { childsii }\end{array}$ & Smooth & Ovate & Pinnatisect & Acute & Absent & $\begin{array}{l}\text { Medium } \\
\text { green }\end{array}$ & Resistant \\
\hline Nephrolepisexaltata & Smooth & Lanceolate & Undulate & Acute & Absent & Light green & Resistant \\
\hline Pterisensiformis & Smooth & linear & Entire & Acute & Absent & $\begin{array}{c}\text { Dark green } \\
\text { with white } \\
\text { markings }\end{array}$ & Resistant \\
\hline $\begin{array}{l}\text { Diplaziumacrostic- } \\
\text { hoides }\end{array}$ & Rough & Lanceolate & Pinnatifide & Acute & Absent & Dark green & $\begin{array}{c}\text { Susceptible } \\
\text { to leaf spot } \\
\text { and leaf } \\
\text { blight }\end{array}$ \\
\hline Nephrolepiscordifolia & Smooth & Reniform & Entire & Round & Absent & Dark green & Nil \\
\hline $\begin{array}{l}\text { Nephrolepisbiserrata } \\
\text { minath }\end{array}$ & Smooth & Lanceolate & Entire & Acute & Absent & Dark green & Resistant \\
\hline Adiantumtenerum & Smooth & Oblong & Entire & Obtuse & Absent & Light green & Resistant \\
\hline $\begin{array}{l}\text { Aspleniumscolopend- } \\
\text { rium }\end{array}$ & Smooth & Triangular & Pinnatisect & Acute & Absent & Dark green & $\begin{array}{c}\text { Highly } \\
\text { susceptible } \\
\text { to leaf spot }\end{array}$ \\
\hline Aspleniumnidus & Smooth & $\begin{array}{l}\text { Oblanceo } \\
\text { late }\end{array}$ & Entire & Obtuse & Absent & $\begin{array}{l}\text { Medium } \\
\text { green }\end{array}$ & Resistant \\
\hline $\begin{array}{l}\text { Nephrolepisbiserrata- } \\
\text { furcans }\end{array}$ & Smooth & Oblong & Dentate & Lobed & Absent & Light green & $\begin{array}{c}\text { Moderately } \\
\text { susceptible } \\
\text { to leaf spot } \\
\text { diseases }\end{array}$ \\
\hline
\end{tabular}




\section{REFERENCES}

Bharati, S. K., Manabendra, D. C. and Behari, M. P. 2013. In-vitro propagation of pteridophytes-A Review. Ind. J. Res. Ayurveda Pharm. 4: 297303.

Lerner, B. R. 2001. Ferns for Indoors. Indoor Hort. 141: $1-3$.

Oloyede, F. A.2012. Survey of ornamental ferns, their morphology and uses for environmental protection, improvement and management. Ife J. Sci. 14: 245-252.
Stamps, R.H. and Conover, C. A. 1986. Cut foliage production in Florida. HortSci.21:343.

Safeena, S. A. 2013. Comprehensive studies on evaluation of ornamental filler plants, for production of cut foliage and vase life. $\mathrm{Ph} . \mathrm{Dt}$ hesis, University of Agricultural Sciences, Bangalore.

Vasco, A., Moran, C. R., and Ambrose, B. A.2013.The evolution, morphology, and development of fern leaves. Plant Sci.4:345.

(Received on 20.11.2017, Revised on 20.11.2019 and accepted on 12.12.2019) 